\title{
Systemic immune-inflammation index in twin pregnancies compared to singleton pregnancies
}

\author{
Ezgi Turgut (D), Bedri Sakcak (D), Deniz Oluklu (D), Şule Göncü Ayhan (D), Dilek Şahin \\ Perinatology Clinic, Ankara City Hospital, Ankara, Turkey
}

\begin{abstract}
Objective: To evaluate the systemic immune-inflammation index (SII) in twin pregnancies.

Methods: The retrospective study included 200 twin (dichorionic/ diamniotic and monochorionic/diamniotic) and 200 singleton pregnancies (control group). All pregnant women were in the first trimester $(<14$ weeks of gestation). The study and the control groups were compared in terms of demographic characteristics, laboratory test results, and SII values.

Results: The mean week of gestation was $9.7 \pm 2$ in dichorionic diamniotic twin pregnancy group, $10.4 \pm 2$ in monochorionic diamniotic twin pregnancy group and $9.4 \pm 2$ for the control group $(\mathrm{p}=0.083$ ). The lymphocyte value was lower in the dichorionic group and monochorionic group than in the control group $(\mathrm{p}=0.020$ and $\mathrm{p}=0.020$, respectively). The platelet-to-lymphocyte ratio (PLR) values were higher in the dichorionic group than in the control group $(\mathrm{p}=0.002)$. However, there was no statistical difference between the groups for neutrophil-to-lymphocyte ratio (NLR) and SII values ( $>>0.05$ ).

Conclusion: Physiological inflammatory/immune reaction of early pregnancy may affect PLR values in twin pregnancies. We observed that chorionicity is considerable for these inflammatory indices, especially for dichorionic twin pregnancies. However, we could not detect a significant change in SII values in twin pregnancy.
\end{abstract}

Keywords: Neutrophil-to-lymphocyte ratio, platelet-to-lymphocyte ratio, systemic immune-inflammation index, twin pregnancy.

\section{Introduction}

Twin pregnancies constitutes $2-4 \%$ of the total number of births. ${ }^{[1,2]}$ Twin pregnancy rate has been increased in the last 30 years due to advanced maternal age and increased application of assisted reproductive tech-
Özet: Tekil gebeliklere kıyasla ikiz gebeliklerde sistemik immün-enflamasyon indeksi

Amaç: İkiz gebeliklerde sistemik immün-enflamasyon indeksini (SII) değerlendirmek.

Yöntem: Retrospektif çalışmaya 200 ikiz (dikoryonik/diamniyotik ve monokoryonik/diamniyotik) ve 200 tekil gebelik (kontrol grubu) dahil edildi. Tüm gebeler birinci trimesterdeydi $(<14$. gebelik haftası). Çalışma ve kontrol grupları, demografik özellikler, laboratuvar test sonuçları ve SII değerleri yönünden karşılaştırıldı.

Bulgular: Ortalama gebelik haftası dikoryonik diamniyotik ikiz gebelik grubunda $9.7 \pm 2$, monokoryonik diamniyotik ikiz gebelik grubunda $10.4 \pm 2$ ve kontrol grubunda $9.4 \pm 2$ ( $\mathrm{p}=0.083$ ) idi. Lenfosit değeri dikoryonik ve monokoryonik gruplarda kontrol grubundan daha düşüktü (sırasıyla $\mathrm{p}=0.020$ ve $\mathrm{p}=0.020$ ). Trombosit-lenfosit oranı (PLR) değerleri dikoryonik grupta kontrol grubundan daha yüksekti $(\mathrm{p}=0.002)$. Ancak nötrofil-lenfosit oranı (NLR) ve SII değerleri bakımından gruplar arasında istatistiksel bir fark yoktu $(\mathrm{p}>0.05)$.

Sonuç: Erken gebeliğin fizyolojik enflamatuvar/immün reaksiyonu, ikiz gebeliklerde PLR değerlerini etkileyebilir. Koryonisitenin bu enflamatuvar indeksler için, özellikle de dikoryonik ikiz gebelikler için dikkate değer olduğunu gözlemledik. Ancak ikiz gebelikte SII değerlerinde anlamlı bir değişiklik tespit edemedik.

Anahtar sözcükler: Nötrofil-lenfosit oranı, trombosit-lenfosit oranı, sistemik immün-enflamasyon indeksi, ikiz gebelik.

niques. ${ }^{[3]}$ Compared to singleton pregnancies, twin pregnancies have an increased risk of obstetric complications such as miscarriage, premature birth, anemia, and gestational hypertension. Altered adaptation during twin pregnancy is a leading cause of these various complica-

\footnotetext{
Correspondence: Ezgi Turgut, MD. Perinatology Clinic, Ankara City Hospital, Üniversiteler Mahallesi 1604. Cadde No: 9 Çankaya, Ankara, Turkey. e-mail: ezgi_sariakcali@hotmail.com / Received: October 22, 2021; Accepted: December 3, 2021

How to cite this article: Turgut E, Sakcak B, Oluklu D, Göncü Ayhan Ş, Şahin D. Systemic immune-inflammation index in twin pregnancies compared to singleton pregnancies. Perinatal Journal 2021;29(3):250-254. doi:10.2399/prn.21.0293014
} 
tions. ${ }^{[4]}$ Immune and inflammatory changes during pregnancy adaptation in twin pregnancies were evaluated with systemic inflammatory markers such as the neutrophil-lymphocyte ratio (NLR) previously, and significant differences were found. ${ }^{[5,6]}$ The systemic immune inflammation index (SII) is a new marker including peripheral lymphocyte, neutrophil, and blood platelet counts. ${ }^{[7]}$ It has been used as a clinical marker to predict the prognosis of the obstetric complications and oncological diseases in various studies. ${ }^{[8-11]}$ In this study, we aim to evaluate the SII in twin pregnancy.

\section{Methods}

The study was conducted in Ankara City Hospital between May 1 and September 15, 2021. Approval for the study was obtained from Ankara City Hospital Ethics Committee with the decision number E2-21131. The retrospective study included 200 twins (144 dichorionic/diamniotic and 56 monochorionic/diamniotic twin pregnancies) and 200 singleton pregnancies and their complete blood counts were evaluated. An inclusion criteria for the groups was having a viable embryo within the first 14 weeks of gestation (first trimester). The gestational age of the pregnancies was established with fetal crown-rump length by ultrasonographic examination. Chorionicity was assigned according to the number of placental masses and $\mathrm{T}$ or $\lambda$-signs for a single placental mass by ultrasonographic examination. Women with fetal chromosomal/structural abnormalities, maternal bleeding, maternal hematologic and systemic diseases, or smoking during pregnancy were excluded. Maternal age, parity, BMI $\left(\mathrm{kg} / \mathrm{m}^{2}\right)$, rate of previous miscarriage (\%), maternal chronic disease (\%), rates of in vitro fertilization (IVF) pregnancies, gestational age at diagnosis (in weeks), maternal hemoglobin $(\mathrm{Hb})(\mathrm{g} / \mathrm{dl})$ count, leukocyte $\left(10^{3} / \mu \mathrm{L}\right)$ count, lymphocyte $\left(10^{3} / \mu \mathrm{L}\right)$ count, neutrophil $\left(10^{3} / \mu \mathrm{L}\right)$ count, platelet $\left(10^{3} / \mu \mathrm{L}\right)$ count, neutrophil-to-lymphocyte ratio (NLR) (neutrophil/lymphocyte), platelet-to-lymphocyte ratio (PLR), and SII (neutrophil $\times$ platelet /lymphocyte) values were compared between the groups.

Statistical analysis was enforced using IBM SPSS Statistics 17.0 (IBM Corporation, Armonk, NY, USA). Descriptive statistics were given as mean \pm standard deviation for numerical data with normal distribution or median and minimum-maximum values for numerical data which do not follow a normal distribution. The normality of the variables was tested with both Shapiro-Wilk and Kolmogorov-Smirnov tests. Oneway ANOVA analysis (and post hoc test to compare groups in case of significant difference was found with univariate ANOVA) was used for statistical analysis of three categorical groups. Comparison of variables were performed by Pearson chi-square test and Fisher's exact test for categorical variables. A p-value $<0.05$ were considered statistically significant.

\section{Results}

The study included 200 twins (144 dichorionic/diamniotic and 56 monochorionic/diamniotic twin pregnancies) and 200 singleton pregnant women. There was no monochorionic/monoamniotic pregnant woman in the study. Table 1 demonstrates study population demographics. The groups showed similar maternal baseline characteristics. The mean week of gestation was $9.7 \pm 2$ in dichorionic diamniotic twin pregnancy group, $10.4 \pm 2$ in

Table 1. Baseline data and characteristics of the groups.

\begin{tabular}{lcccc} 
& $\begin{array}{c}\text { Control group } \\
(\mathbf{n = 2 0 0 )}\end{array}$ & $\begin{array}{c}\text { Dichorionic group } \\
(\mathbf{n = 1 4 4 )}\end{array}$ & $\begin{array}{c}\text { Monochorionic group } \\
(\mathbf{n = 5 6 )}\end{array}$ & $\mathbf{p}$-value \\
\hline Maternal age & $28.1 \pm 5.2$ & $29.4 \pm 5.2$ & $28.5 \pm 5.4$ & 0.143 \\
\hline BMl $\left(\mathrm{kg} / \mathrm{m}^{2}\right)$ & $26.2 \pm 5.2$ & $27.0 \pm 4.9$ & $27.3 \pm 5.4$ & 0.244 \\
\hline IVF & $24(12 \%)$ & $26(18.1 \%)$ & $9(16.1 \%)$ & 0.282 \\
\hline Nulliparity & $48(24 \%)$ & $33(22.9 \%)$ & $15(26.8 \%)$ & 0.296 \\
\hline Previous miscarriage $(\geq 1)$ & $26(13 \%)$ & $25(17.4 \%)$ & $6(10.7 \%)$ & 0.374 \\
\hline Gestational age (week) & $9.4 \pm 2$ & $9.7 \pm 2$ & $10.4 \pm 2$ & 0.083 \\
\hline Maternal chronic disease & $11(5.5 \%)$ & $8(5.6 \%)$ & $5(8.9 \%)$ & 0.609 \\
\hline
\end{tabular}

Data given as mean \pm standard deviation. BMI: body mass index; IVF: in vitro fertilization. 
monochorionic diamniotic twin pregnancy group and $9.4 \pm 2$ for the control group ( $\mathrm{p}=0.083)$. In Table 2, laboratory test results and SII values were compared between singleton, dichorionic/diamniotic and monochorionic/diamniotic twin pregnancy groups. There was a significant difference between the groups for $\mathrm{Hb}$, lymphocyte and PLR values $(\mathrm{p}=0.001, \mathrm{p}=0.016$ and $\mathrm{p}=0.007$, respectively). $\mathrm{Hb}$ level in maternal blood were significantly lower in the both dichorionic and monochorionic groups than in the control group $(\mathrm{p}=0.002, \mathrm{p}=0.004$, respectively). The lymphocyte value was lower in the dichorionic and monochorionic groups than in the control group $(\mathrm{p}=0.020$ and $\mathrm{p}=0.020$, respectively). The platelet-to-lymphocyte ratio (PLR) values were higher in the dichorionic group than in the control group $(\mathrm{p}=0.002)$. However, there was no statistical difference between the groups for neutrophil-to-lymphocyte ratio $(\mathrm{NLR})$ and SII values $(\mathrm{p}>0.05)$.

\section{Discussion}

Twin pregnancy is represented as a high-risk pregnancy due to increased adverse pregnancy outcomes. We hypothesized that first trimester hyperimmune changes may occur in twin pregnancies compared to singletons and consistently we found significantly higher values of PLR in dichorionic diamniotic twin pregnancies than controls. However, there was no difference in all groups for SII values.

In pregnant women, local adaptation of the maternal immune system allows for successful coexistence between the mother and the fetus. ${ }^{[12]}$ Cytotoxic adaptive immune responses are diminished, while regulatory adaptive immunity is enhanced. ${ }^{[1,14]}$ The fetal membranes and placental trophoblasts are directly exposed to maternal blood and tissues. The number of fetuses is significantly correlated with the activity of trophoblasts. ${ }^{[15]}$ The studies have reported that twin pregnancies produce more trophoblasts than singleton pregnancies during the first trimester. ${ }^{[6,16]}$ The $\mathrm{T}$ helper 1 (Th1): $\mathrm{T}$ helper 2 (Th2) balance was compared between twin and singleton pregnancies in the first trimester. ${ }^{[6]}$ The mean Th1:Th2 ratio in twin pregnancies was found to be significantly lower than in singleton pregnancies, associated with increased maternal serum hCG levels. ${ }^{[6]}$

There is a growing number of studies evaluating altered immunity and inflammation-related obstetric complications. The NLR and PLR values were reported to be sensitive early biomarkers of inflammatory response in obstetric conditions. ${ }^{[17-19]}$ NLR was found significantly higher in patients with preeclampsia, hyperemesis gravidarum, and cholestasis of pregnancy that all related with hyperinflammation. ${ }^{[17-19]}$ Sabre et al. ${ }^{[5]}$ evaluated 29 twin and 29 singleton pregnancies in the first trimester. They found that NLR was significantly higher in twin pregnancies. However, they found no difference in PLR values between groups. Contrarily, we observed significantly higher PLR values in the dichorionic diamniotic twin pregnancies than singleton pregnancies. This may be related to the low lymphocyte levels in the twin pregnancy group. However, there was an increase in NLR and SII values in both dichorionic and

Table 2. Comparison of laboratory test results and SIl values between singleton pregnancy, dichorionic/diamniotic and monochorionic/diamniotic twin pregnancy groups.

\begin{tabular}{lcccc} 
& $\begin{array}{c}\text { Control group } \\
(\mathbf{n}=\mathbf{2 0 0})\end{array}$ & $\begin{array}{c}\text { Dichorionic group } \\
(\mathbf{n = 1 4 4 )}\end{array}$ & $\begin{array}{c}\text { Monochorionic group } \\
(\mathbf{n}=\mathbf{5 6})\end{array}$ & $\mathbf{p}$-value \\
\hline $\mathrm{Hb}(\mathrm{g} / \mathrm{dl})$ & $12.6 \pm 1.1$ & $12.2 \pm 1.2^{*}$ & $12.1 \pm 1.3^{+}$ & 0.001 \\
\hline Leukocyte $\left(10^{3} / \mathrm{hL}\right)$ & $8.5 \pm 2.6$ & $8.1 \pm 2.6$ & $8.9 \pm 2.3$ & 0.160 \\
\hline Neutrophil $\left(10^{3} / \mathrm{LL}\right)$ & $6.7 \pm 3.1$ & $6.5 \pm 2.3$ & $6.4 \pm 2.1$ & 0.737 \\
\hline Lymphocyte $\left(10^{3} / \mathrm{\mu L}\right)$ & $2.0 \pm 0.7$ & $1.8 \pm 0.6^{*}$ & $1.7 \pm 0.4^{+}$ & 0.016 \\
\hline Platelet $\left(10^{3} / \mu \mathrm{L}\right)$ & $269.0 \pm 71.2$ & $269.3 \pm 61.7$ & $264.1 \pm 62.8$ & 0.875 \\
\hline NLR & $3.6 \pm 2.1$ & $4.4 \pm 2.1$ & $4.1 \pm 2.1$ & 0.055 \\
\hline PLR & $146.2 \pm 58.3$ & $184.7 \pm 70.3^{*}$ & $156.9 \pm 48.5$ & 0.007 \\
\hline SII $\left(10^{9} / \mathrm{L}\right)$ & $955.95 \pm 53.5$ & $1178.45 \pm 120.7$ & $1057.19 \pm 474.6$ & 0.052 \\
\hline
\end{tabular}

Data given as mean \pm standard deviation. *Statistically significant difference between dichorionic group and control group ( $<<0.05)$; ${ }^{\dagger}$ statistically significant difference between monochorionic group and control group $(\mathrm{p}<0.05)$. Control: singleton pregnancies; Hb: hemoglobin; NLR: neutrophil-to-lymphocyte ratio; PLR: platelet-to-lymphocyte ratio; SII: systemic immune inflammation index. 
monochorionic twin pregnancies, but no statistically significant difference was observed compared to the control group. The SII is a new marker that incorporates lymphocyte, neutrophil, and platelet parameters known to be associated with inflammation. ${ }^{[7,8]}$ For predicting oncological disease prognosis, SII was used in different studies. ${ }^{[7]}$ The SII value was evaluated for prediction of adverse neonatal outcomes in preterm premature rupture of membranes (PPROM), and researchers found significantly increased SII values in the patients with PPROM. ${ }^{[10]}$

Monochorionic twin pregnancies have higher perinatal complication risks than dichorionic twin pregnancies. ${ }^{[20]}$ Riyami et al. ${ }^{[2]]}$ observed that high perinatal morbidity and mortality rate is likely due to frequent twinto-twin transfusion syndrome, prematurity, fetal growth restriction, and intrauterine fetal death. It has been investigated that it may cause high adverse pregnancy outcomes due to the greater fetomaternal antigenic differences in monochorionic pregnancies. However, Savvidou et al..$^{[2]}$ evaluated 666 twin pregnancies, and they observed chorionicity does not affect the incidence of preeclampsia in twin pregnancies. In this study, we compared NRL, PLR, and SII data in monochorionic and dichorionic twin pregnancies, considering the high rate of adverse pregnancy outcomes in monochorionic pregnancies. On the contrary, we did not detect any significant difference between monochorionic and dichorionic pregnancies. However, dichorionic twin pregnancy group had a significantly increased PLR values compared to singleton pregnancies. Placental weight is higher in dichorionic twin pregnancies compared to monochorionic pregnancies. ${ }^{[23]}$ Therefore, it could be assumed that markers associated with inflammation may contribute to the higher immunological load with placental mass in dichorionic pregnancies. ${ }^{[2]}$

\section{Conclusion}

In conclusion, there was significantly higher PLR values in twin pregnancies compared to controls. In addition, we observed that chorionicity is considerable for these inflammatory indices, especially for dichorionic twin pregnancies. This is the first study to evaluate the SII values in twin pregnancies. Future studies are needed to evaluate the relationship between SII assessment and adverse pregnancy outcomes in twin pregnancies.
Our study has strengths and weaknesses. It is the first study to evaluate the SII value in twin pregnancies. Using of an inexpensive and easy-to-apply method against underestimation is the strength of our study. The limitation of our study is the retrospective evaluation of the data and lack of long-term outcomes of the study group.

Funding: This work did not receive any specific grant from funding agencies in the public, commercial, or not-for-profit sectors.

Compliance with Ethical Standards: The authors stated that the standards regarding research and publication ethics, the Personal Data Protection Law and the copyright regulations applicable to intellectual and artistic works are complied with and there is no conflict of interest.

\section{References}

1. Collins J. Global epidemiology of multiple birth. Reprod Biomed Online 2007;15 Suppl 3:45-52. [PubMed] [CrossRef]

2. Scaranello Santana D, Garanhani Surita F, Guilherme Cecatti J. Multiple pregnancy: epidemiology and association with maternal and perinatal morbidity. Rev Bras Ginecol Obstet 2018;40:554-62. [PubMed] [CrossRef]

3. National Collaborating Centre for Women's and Children's Health (UK). Multiple pregnancy: the management of twin and triplet pregnancies in the antenatal period. London: RCOG Press; 2011. [PubMed]

4. Young BC, Wylie BJ. Effects of twin gestation on maternal morbidity. Semin Perinatol 2012;36:162-8. [PubMed] [CrossRef]

5. Sabre A, Sisti G, Gaither K. Neutrophil-to-lymphocyte ratio and platelet-to-lymphocyte ratio in twins compared with singletons. South Med J 2021;114:28-31. [PubMed] [CrossRef]

6. Suzuki S, Okudaira S. Maternal peripheral T helper 1-type and $\mathrm{T}$ helper 2-type immunity in women during the first trimester of twin pregnancy. Arch Gynecol Obstet 2004;270: 260-2. [PubMed] [CrossRef]

7. Hu B, Yang XR, Xu Y, Sun YF, Sun C, Guo W, et al. Systemic immune-inflammation index predicts prognosis of patients after curative resection for hepatocellular carcinoma. Clin Cancer Res 2014;20:6212-22. [PubMed] [CrossRef]

8. Chen JH, Zhai ET, Yuan YJ, Wu KM, Xu JB, Peng JJ, et al. Systemic immune-inflammation index for predicting prognosis of colorectal cancer. World J Gastroenterol 2017;23:6261-72. [PubMed] [CrossRef]

9. Deng C, Zhang N, Wang Y, Jiang S, Lu M, Huang Y, et al. High systemic immune-inflammation index predicts poor prognosis in advanced lung adenocarcinoma patients treated with EGFR-TKIs. Medicine (Baltimore) 2019;98:e16875. [PubMed] [CrossRef]

10. Tanacan A, Uyanik E, Unal C, Beksac MS. A cut-off value for systemic immune-inflammation index in the prediction 
of adverse neonatal outcomes in preterm premature rupture of the membranes. J Obstet Gynaecol Res 2020;46:1333-41. [PubMed] [CrossRef]

11. Orgul G, Agbal T, Celen S, Caglar AT. Neuroprotective magnesium sulfate administration increases maternal neutrophilto-lymphocyte ratio, platelet-to-lymphocyte ratio and systemic immune-inflammation index. Arch Gynecol Obstet 2021;303: 1433-7. [PubMed] [CrossRef]

12. Robertson SA. Immune regulation of conception and embryo implantation-all about quality control? J Reprod Immunol 2010;85:51-7. [PubMed] [CrossRef]

13. Guerin L, Prins JR, Robertson SA. Regulatory T-cells and immune tolerance in pregnancy: a new target for infertility treatment? Human Reprod Update 2009;15:517-35. [PubMed] [CrossRef]

14. Leber A, Teles A, Zenclussen AC. Regulatory T cells and their role in pregnancy. Am J Reprod Immunol (New York, NY: 1989) 2010;63:445-59. [PubMed] [CrossRef]

15. Johnson MR, Abbas A, Nicolaides KH. Maternal plasma levels of human chorionic gonadotrophin, oestradiol and progesterone in multifetal pregnancies before and after fetal reduction. J Endocrinol 1994;143:309-12. [PubMed] [CrossRef]

16. Grün JP, Meuris S, De Nayer P, Glinoer D. The thyrotrophic role of human chorionic gonadotrophin (hCG) in the early stages of twin (versus single) pregnancies. Clin Endocrinol (Oxf) 1997;46:719-25. [PubMed] [CrossRef]
17. Caglayan EK, Engin-Ustun Y, Gocmen AY, Sarı N, Seckin L, Kara M, et al. Is there any relationship between serum sirtuin1 level and neutrophil-lymphocyte ratio in hyperemesis gravidarum? J Perinat Med 2016;44:315-20. [PubMed] [CrossRef]

18. Kirbas A, Ersoy AO, Daglar K, Dikici T, Biberoglu EH, Kirbas O, et al. Prediction of preeclampsia by first trimester combined test and simple complete blood count parameters. J Clin Diagn Res 2015;9:QC20-3. [PubMed] [CrossRef]

19. Kirbas A, Biberoglu E, Daglar K, Iskender C, Erkaya S, Dede $\mathrm{H}$, et al. Neutrophil-to-lymphocyte ratio as a diagnostic marker of intrahepatic cholestasis of pregnancy. Eur J Obstet Gynecol Reprod Biol 2014;180:12-5. [PubMed] [CrossRef]

20. Powers WF, Kiely JL. The risks confronting twins: a national perspective. Am J Obstet Gynecol 1994;170:456-61. [PubMed] [CrossRef]

21. Al-Riyami N, Al-Rusheidi A, Khoud A, Murtadha Al-Khabori O, al Riyami N, Oman A-K. Perinatal outcome of monochorionic in comparison to dichorionic twin pregnancies. Oman Med J 2013;28:173-7. [PubMed] [CrossRef]

22. Savvidou MD, Karanastasi E, Skentou C, Geerts L, Nicolaides $\mathrm{KH}$. Twin chorionicity and pre-eclampsia. Ultrasound Obstet Gynecol 2001;18:228-31. [PubMed] [CrossRef]

23. De Paepe ME, Shapiro S, Young LE, Luks FI. Placental weight, birth weight and fetal:placental weight ratio in dichorionic and monochorionic twin gestations in function of gestational age, cord insertion type and placental partition. Placenta 2015;36:213-20. [PubMed] [CrossRef]

This work is licensed under the Creative Commons Attribution-NonCommercial-NoDerivs 4.0 Unported (CC BY-NC-ND4.0) License. To view a copy of this license, visit http://creativecommons.org/licenses/by-nc-nd/4.0/ or send a letter to Creative Commons, PO Box 1866, Mountain View, CA 94042, USA.

Publisher's Note: The content of this publication does not necessarily reflect the views or policies of the publisher, nor does any mention of trade names, commercial products, or organizations imply endorsement by the publisher. Scientific and legal responsibilities of published manuscript belong to their author(s). The publisher remains neutral with regard to jurisdictional claims in published maps and institutional affiliations. 